\title{
DEPRESSION OF THE EXOGENOUS CREATININE/INULIN OR THIOSULFATE CLEARANCE RATIOS IN MAN BY DIODRAST AND p-AMINOHIPPURIC ACID ${ }^{1}$
}

\author{
By BETTY CRAWFORD \\ (From the Department of Physiology, New York University College of Medicine, \\ New York City)
}

(Received for publication August 25, 1947)

Exogenous creatinine is excreted by the renal tubules of the aglomerular fish (1 to 4), the glomerular dogfish $(5,6)$, teleost $(7)$ and chicken (8), but not by the frog (9), turtle (10), dog (11 to 14$)$, sheep (15), seal (16), rabbit (17) or cat (18). Among the mammals tubular excretion is recorded only in the anthropoid apes $(19,20)$ and man $(21)$.

The evidence for tubular excretion in man, as initially advanced by Shannon, consists of the facts that (1) the exogenous creatinine/inulin clearance ratio exceeds 1.0 (ranging from 1.2 to 1.7) $(21,22,23)$; (2) this ratio is depressed towards 1.0 by raising the plasma level of creatinine (21) ; (3) at all plasma levels, the creatinine/inulin clearance ratio is depressed towards 1.0 by phlorhizin (21) which is known to depress the tubular excretion of phenol red (24) and diodrast (25).

Winkler and Parra (26) observed that after the ingestion of creatinine, both the creatinine clearance and the creatinine/sucrose clearance ratio behaved erratically and generally fell as the experiment proceeded, and they believed that this progressive fall with time represented the same phenomenon as the self-depression of the clearance at high plasma levels. Shannon and Ranges (27) have, however, presented evidence to refute this view. They have shown that $(a)$ the creatinine/inulin clearance ratio does not fall markedly with time if the plasma level is maintained by the continuous infusion of creatinine, $(b)$ a second dose of creatinine elevates the clearance ratio, after this has been depressed by the lapse of time, towards the values observed shortly after a first dose, and (c) this elevation occurs only if the ratio has been depressed by virtue of the prolonged circulation of creatinine in the body. These ob-

1 Aided by a grant from the Commonwealth Fund. servations appear to exclude 'fatigue' and 'stimulation' of the excretory mechanism. They accord with the possibility suggested by the above investigators; namely, that in the body creatinine is converted in part to a compound which, though still giving the Jaffe reaction, is less readily excreted by the tubules; or, alternatively, to a compound which blocks excretion by virtue of a high competitive affinity for some component of the excretion mechanism. This latter possibility is rendered more plausible by the recent description of caronamide (28), a compound not excreted by the tubules but one which blocks the excretion of some other substances (phenol red, diodrast, penicillin, etc.).

The evidence for the tubular excretion of exogenous creatinine in man has not been convincing to all writers (29) and it has seemed desirable to examine the matter further.

Substances excreted by the renal tubules appear in general to interfere in the excretion of other substances, presumably by competition for some enzyme system or source of energy. Thus diodrast and hippuran depress the excretion of phenol red and vice-versa $(30,31)$, hippuric acid depresses the excretion of phenol red (32), as do iopax, skiodan and neoiopax (33), while diodrast (34) and p-aminohippuric acid (35) depress the tubular excretion of penicillin. ${ }^{2}$

\section{EXPERIMENTAL}

It seemed possible that if creatinine is excreted by tubules in man, the simultaneous excretion of large quantities of diodrast or p-aminohippuric acid (PAH) would depress the creatinine/inulin clearance ratio. Consequently, we have made a number of observations in which

2 A possible exception to this interference phenomenon is observed in the dogfish, where creatinine, though copiously excreted by the renal tubules, has only slight effect on the simultaneous excretion of phenol red. The single experiment reported is, however, equivocal (31). 
this ratio was first determined during three consecutive control periods of some 10 minutes each. They were examined again during a second series of three consecutive periods 20 to 60 minutes after the intravenous administration of large doses of diodrast (15 to $30 \mathrm{cc}$. of 35 per cent solution) or PAH ( 30 to $50 \mathrm{cc}$. of 20 per cent solution), supported by the intravenous infusion of sufficient quantities of these substances to maintain high plasma concentrations. (See Table I for plasma concentrations.) Creatinine was administered intravenously in normal saline in priming and sustaining infusions in suffcient doses to maintain a plasma level of 7 to $15 \mathrm{mg}$. per cent. Since Newman, Gilman and Phillips (36) have shown that the thiosulfate clearance is essentially identical with the inulin clearance in man, ${ }^{3}$ we have included a number of creatinine/thiosulfate clearance comparisons carried out in the same manner.

3 This identity has been amply confirmed in this laboratory in observations not reported here.
Clearances, performed by the standard infusion technic with priming and sustaining infusions and bladder catheterization (37), were measured in convalescent female patients without renal disease selected from various wards of the Third (New York University) Division of Bellevue Hospital. A $1: 10$ or $1: 15$ cadmium sulfate filtrate of plasma (32) was used for creatinine and inulin determination, and a 1:10 tungstate filtrate (36) for thiosulfate. Creatinine was determined by the alkaline picrate method (32), inulin determined by Harrison's method (38) and thiosulfate by the method of Newman, Gilman and Phillips (36).

\section{RESULTS}

Our results are shown in Table I, which presents all the data pertinent to the interpretation of the experiments.

During the control periods we have consistently observed an inulin/creatinine clearance ratio in

TABLE I

The effects of large doses of p-aminohippuric acid and diodrast on the creatinine/inulin and creatinine/thiosulfate clearance ratios in man

\begin{tabular}{|c|c|c|c|c|c|c|c|c|c|c|c|c|}
\hline \multirow{2}{*}{$\begin{array}{l}\text { Date } \\
1946\end{array}$} & \multirow{2}{*}{$\begin{array}{c}\mathrm{Pa}- \\
\text { tient }\end{array}$} & \multicolumn{4}{|c|}{ Plasma concentration* } & \multicolumn{3}{|c|}{ Clearance } & \multicolumn{3}{|c|}{ Clearance ratios } & \\
\hline & & Creat. & Inulin & Thio. & PAH & Creat. & Inulin & Thio. & $\frac{\text { Creat. }}{\text { Inulin }}$ & $\frac{\text { Creat. }}{\text { Thio. }}$ & Thio. & \\
\hline $\begin{array}{l}10 / 16 \\
10 / 21 \\
10 / 23 \\
10 / 30 \\
11 / 1 \\
11 / 6 \\
11 / 8 \\
11 / 13\end{array}$ & $\begin{array}{l}\text { AP } \\
\text { DP } \\
\text { VA } \\
\text { DK } \\
\text { DK } \\
\text { AA } \\
\text { CM } \\
\text { JJ }\end{array}$ & $\begin{array}{c}10.8-9.7 \\
8.4-8.2 \\
12.4-11.9 \\
10.8-9.9 \\
9.2-9.2 \\
8.8-8.8 \\
9.1-8.0 \\
6.2-6.6 \\
10.3-9.7 \\
9.7-9.1 \\
12.8-12.2 \\
11.4-11.4 \\
14.3-12.8 \\
11.4-11.6 \\
7.6-7.6 \\
9.0-8.8\end{array}$ & $\begin{array}{l}16.0-14.2 \\
10.7-11.2 \\
22.0-17.2 \\
11.9-11.8 \\
20.0-15.0 \\
12.8-11.3 \\
25.6-21.2 \\
17.8-17.6 \\
22.2-20.0 \\
16.3-17.8 \\
15.0-13.8 \\
16.7-14.4\end{array}$ & $\begin{array}{l}18.2-15.2 \\
11.7-10.8 \\
20.4-20.4 \\
16.4-16.4 \\
17.0-17.9 \\
16.0-15.9 \\
15.0-12.9 \\
11.4-10.0 \\
18.5-17.3 \\
16.7-15.4 \\
24.3-22.8 \\
20.7-21.2 \\
20.6-19.8 \\
19.8-19.1 \\
14.7-12.8 \\
10.7-9.5\end{array}$ & $\begin{array}{l}73-92 \\
57-43 \\
42-57 \\
17-29 \\
58-65 \\
60-65 \\
40-51 \\
35-38\end{array}$ & $\begin{array}{l}180 \\
113 \\
181 \\
141 \\
164 \\
127 \\
229 \\
181 \\
231 \\
168 \\
158 \\
125 \\
139 \\
98.9 \\
215 \\
166\end{array}$ & \begin{tabular}{|l|}
139 \\
134 \\
182 \\
149 \\
181 \\
141 \\
129 \\
116 \\
109 \\
94.6 \\
172 \\
133
\end{tabular} & $\begin{array}{c}c c . \text { per } \\
\text { min. } \\
143 \\
131 \\
119 \\
103 \\
101 \\
94 \\
168 \\
146 \\
\\
\text { Avg. } \\
\text { Avg. } \\
151 \\
116 \\
150 \\
134 \\
137 \\
125 \\
175 \\
154 \\
164 \\
138 \\
124 \\
121 \\
110 \\
83.9 \\
174 \\
158 \\
\\
\text { Avg. } \\
\text { Avg. }\end{array}$ & $\begin{array}{l}1.20 \\
0.948 \\
1.26 \\
1.22 \\
1.28 \\
1.19 \\
1.23 \\
1.08 \\
1.28 \\
1.05 \\
1.24 \\
(1.25) \dagger \\
1.25 \\
1.10\end{array}$ & $\begin{array}{l}1.23 \\
0.956 \\
1.14 \\
0.974 \\
1.48 \\
1.23 \\
1.31 \\
0.988 \\
1.29 \\
1.04 \\
\\
1.20 \\
0.984 \\
1.21 \\
1.05 \\
1.21 \\
1.02 \\
1.31 \\
1.19 \\
1.42 \\
1.23 \\
1.27 \\
1.03 \\
1.27 \\
1.18 \\
1.14 \\
1.05 \\
1.25 \\
1.09\end{array}$ & $\begin{array}{l}0.988 \\
0.929 \\
0.967 \\
1.03 \\
0.904 \\
0.969 \\
0.966 \\
1.05 \\
1.00 \\
0.891 \\
0.983 \\
(1.19) \dagger \\
\\
0.969 \\
0.990\end{array}$ & $\begin{array}{l}\text { Control } \\
\text { After diodrast } \\
\text { Control } \\
\text { After diodrast } \\
\text { Control } \\
\text { After diodrast } \\
\text { Control } \\
\text { After diodrast } \\
\text { Control } \\
\text { After diodrast } \\
\text { Control } \\
\text { After PAH } \\
\text { Control } \\
\text { After PAH } \\
\text { Control } \\
\text { After PAH } \\
\text { Control } \\
\text { After PAH } \\
\text { Control } \\
\text { After PAH } \\
\text { Control } \\
\text { After PAH } \\
\text { Control } \\
\text { After PAH } \\
\text { Control } \\
\text { After PAH } \\
\text { Control } \\
\text { After PAH }\end{array}$ \\
\hline
\end{tabular}

* Plasma concentrations of diodrast not determined.

† Omitted from averages. 
excess of 1.0 (range 1.12 to 1.29 ) and a creatinine/ thiosulfate clearance ratio in excess of 1.0 (1.14 to 1.48 ).

After the administration of diodrast or $\mathrm{PAH}$ these ratios (with the single exception of the creatinine/inulin ratio in J. J.) have dropped, in many cases to values slightly under or slightly above 1.0. In a single subject, diodrast lowered the creatinine/inulin clearance ratio from 1.29 to 1.09. In 6 subjects this ratio averaged 1.25 before, and 1.10 after PAH. The creatinine/thiosulfate ratio in 4 subjects averaged 1.29 before and 1.04 after diodrast; while in 8 subjects this ratio averaged 1.25 before and 1.09 after PAH. (The last figure omits $\mathrm{J}$. J. where an aberrantly large thiosulfate/inulin ratio of 1.19 indicates a possible erroneously low inulin clearance in the last half of the experiment.)

Our data on the simultaneous thiosulfate/inulin clearance ratio (average of 21 periods in 7 subjects, 0.97 , range 0.891 to 1.10 , excluding J. J.) confirm Newman, Gilman and Phillips (36) in their conclusion that the thiosulfate and inulin clearances are identical in man. ${ }^{4}$ After the administration of diodrast or $\mathrm{PAH}$ this ratio averaged 0.99 ( 18 periods in 6 subjects), indicating that these substances do not disturb the excretion of either thiosulfate or inulin.

If it is argued that the exogenous creatinine clearance is at the level of glomerular filtration in man, then a creatinine/inulin ratio in excess of 1.0 indicates active tubular reabsorption of inulin, since inulin is completely ultrafiltrable from plasma (39). Reduction of this ratio to or towards 1.0 by the administration of diodrast or $\mathrm{PAH}$ could only be explained by supposing ( $a$ ) that this tubular reabsorption is blocked by these compounds, or (b) that the permeability of the tubules was so increased as to permit creatinine (and to a lesser extent) inulin to escape from the urine to such an extent as approximately to equalize the clearances. Under supposition $(a)$, the fact that the inulin and thiosulfate clearances are, within experimental error, identical before and after the administration of diodrast and $\mathrm{PAH}$ would require not only that

\footnotetext{
$4 \mathrm{We}$ are inclined to believe that the large scatter in our ratios is in part attributable to variations in the large thiosulfate blank in the plasma, a definite disadvantage in this method as compared with inulin.
}

thiosulfate be reabsorbed to the same extent as inulin, but that diodrast and $\mathrm{PAH}$ have a similar effect in blocking the reabsorption of both compounds, while the failure of diodrast to produce glycursuria would require that this compound block the reabsorption of inulin but not that of glucose. All three possibilities seem to us to be highly improbable. In respect to $(b)$, it will be noted that in all cases the absolute creatinine, inulin and thiosulfate clearances decreased after the administration of large doses of diodrast or $\mathrm{PAH}$, a phenomenon which in respect to the inulin clearance is well recognized (30). This decreased clearance might be interpreted as indicating tubular injury and back-diffusion except for the fact that the clearances tend to return to control values despite the maintenance of high plasma levels of these compounds. It is well known that both compounds when given in large amounts may produce vasomotor and other autonomic responses (burning of the skin, sweating, headache, cramps, nausea and sometimes rectal contraction [40]). The variable and transient depression of renal clearances may reasonably be attributed to disturbances of the glomerular circulation. There is no evidence that substances (diodrast and PAH) copiously excreted by the renal tubules increase their permeability, or that this increase would be of such a nature as to maintain the identity of the inulin and thiosulfate clearances and approximately to equalize these clearances with that of creatinine.

We are therefore inclined to accept the simpler interpretation; namely, that the inulin and thiosulfate clearances are at the level of glomerular filtration and that the exogenous creatinine clearance exceeds both the other clearances because of the tubular excretion of this compound, this tubular excretion being depressed and the creatinine clearance being reduced to or towards the inulin and thiosulfate clearance by diodrast and $\mathrm{PAH}$ in consequence of some type of intracellular competition.

This conclusion extends the evidence for the tubular excretion of creatinine as advanced by Shannon (21) and Shannon and Ranges (27), and confirms that reviewed elsewhere on the mechanism of excretion of inulin (39). 


\section{SUMMARY}

It is confirmed that in normal man the exogenous creatinine clearance exceeds the simultaneous inulin or thiosulfate clearance to an extent clearly beyond the limits of experimental error.

In 39 periods in 7 subjects, the thiosulfate/inulin clearance ratio averages 0.98 , confirming the conclusion of Newman, Gilman and Phillips that the thiosulfate clearance is at the level of glomerular filtration.

The administration of large doses of diodrast or PAH (substances known to be copiously excreted by the renal tubules in man) depresses the creatinine/inulin and creatinine/thiosulfate ratio to or towards 1.0. These facts are presented as new evidence for the tubular excretion of exogenous creatinine, and confirm the belief that in man as in other mammals the inulin clearance is at the level of glomerular filtration.

\section{BIBLIOGRAPHY}

1. Marshall, E. K., Jr., and Grafflin, A. L., The structure and function of the kidney of Lophius piscatorius. Bull. Johns Hopkins Hosp., 1928, 43, 205.

2. Marshall, E. K., Jr., and Grafflin, A. L., The function of the proximal convoluted segment of the renal tubule. J. Cell. \& Comp. Physiol., 1932, 1, 161.

3. Edwards, J. G., and Condorelli, L., Studies on aglomerular and glomerular kidneys. II. Physiological. Am. J. Physiol., 1928, 86, 383.

4. Shannon, J. A., Renal excretion of exogenous creatinine in the aglomerular toadfish, Opsanus tau. Proc. Soc. Exper. Biol. \& Med., 1938, 38, 245.

5. Shannon, J. A., The excretion of inulin by the dogfish, 'Squalus acanthias. J. Cell. \& Comp. Physiol., 1934, 5, 301.

6. Shannon, J. A., On the mechanism of the renal tubular excretion of creatinine in the dogfish, Squalus acanthias. J. Cell. \&'Comp. Physiol., 1940, 16, 285.

7. Pitts, R. F., Excretion of creatine by the marine teleost, the red grouper. Ann. Rep. Tortugas Lab., Carnegie Inst. of Wash. 1935-36, pp. 90, 91.

8. Shannon, J. A., The excretion of exogenous creatinine by the chicken. J. Cell. \& Comp. Physiol., 1938, 11, 123.

9. Forster, R. P., The use of inulin and creatinine as glomerular filtrate measuring substances in the frog. J. Cell. \& Comp. Physiol., 1938, 12, 213.

10. Friedlich, A., Holman, C. B., and Forster, R. P., Renal clearance studies in the fresh-water turtle, Pseudemys elegans. Bull. The Mount Desert Island Biol. Lab., 1940.
11. Richards, A., Westfall, B., and Bott, P., Inulin and creatinine clearances in dogs, with notes on some late effects of uranium poisoning. J. Biol. Chem., 1937, 116, 749.

12. Shannon, J. A., The excretion of inulin by the dog. Am. J. Physiol., 1935, 112, 405.

13. Shannon, J. A., The excretion of inulin and creatinine at low urine flows by the normal dog. Am. J. Physiol., 1936, 114, 362.

14. Van Slyke, D. D., Hiller, A., and Miller, B. F., The clearance, extraction percentage and estimated filtration of sodium ferrocyanide in the mammalian kidney. Comparison with inulin, creatinine and urea. Am. J. Physiol., 1935, 113, 611.

15. Shannon, J. A., Excretion of inulin, creatinine, xylose and urea in the sheep. Proc. Soc. Exper. Biol. \& Med., 1937, 37, 379.

16. Smith, H. W., The composition of urine in the seal. J. Cell. \& Comp. Physiol., 1936, 7, 465.

17. Kaplan, B. I., and Smith, H. W., Excretion of inulin, creatinine, xylose and urea in the normal rabbit. Am. J. Physiol., 1935, 113, 354.

18. Gammeltoft, A., and Kjerulf-Jensen, $K$., The mechanism of renal excretion of fructose and galactose in rabbit, cat, dog and man (with special reference to the phosphorylation theory). Acta Physiol. Scand., 1943, 6, 368.

19. Smith, H. W., and Clarke, R. W., The excretion of inulin and creatinine by the anthropoid apes and other infrahuman Primates. Am. J. Physiol., 1938, 122, 132.

20. Houck, C. R., Personal communication.

21. Shannon, J. A., The renal excretion of creatinine in man. J. Clin. Invest., 1935, 14, 403.

22. McCance, R. A., and Widdowson, E. M., Alkalosis with disordered kidney functions; observations on a case. The Lancet, 1937, 2, 247.

23. Josephson, B., and Lindahl, O., On the reliability of the inulin clearance, together with a comparison between this and the creatinine clearance. Acta med. Scandinav., 1943, 116, 20.

24. Chasis, H., Ranges, H. A., Goldring, W., and Smith, H. W., The control of renal blood flow and glomerular filtration in normal man. J. Clin. Invest., 1938, 17, 683.

25. White, H. L., The effects of phlorhizin on renal plasma flow, on glomerular filtration and on the tubular excretion of diodrast in the dog. Am. J. Physiol., 1940, 130, 582.

26. Winkler, A. W., and Parra, J., The measurement of glomerular filtration. Creatinine, sucrose and urea clearances in subjects without renal disease. $J$. Clin. Invest., 1937, 16, 859.

27. Shannon, J. A., and Ranges, H. A., On the renal tubular excretion of creatinine in normal man. J. Clin. Invest., 1941, 20, 169.

28. Beyer, K. H., Personal communication.

29. Ekehorn, G., Inulin as a substitute for creatinine in renal tests. Acta med. Scandinav., 1944, 118, 114. 
30. Smith, H. W., Goldring, W., and Chasis, H., The measurement of the tubular excretory mass, effective blood flow and filtration rate in the normal human kidney. J. Clin. Invest., 1938, 17, 263.

31. Smith, W. W., The excretion of phenol red in the dogfish Squalus acanthias. J. Cell. \& Comp. Physiol., 1939, 14, 357.

32. Smith, H. W., Finkelstein, N., Aliminosa, L., Crawford, B., and Graber, M., The renal clearances of substituted hippuric acid derivatives and other aromatic acids in dog and man. J. Clin. Invest., 1945, 24, 388.

33. Smith, W. W., and Ranges, H. A., Renal clearances of iopax, neoiopax and skiodan in man. Am. J. Physiol., 1938, 123, 720.

34. Rammelkamp, C. H., and Bradley, S. E., Excretion of penicillin in man. Proc. Soc. Exper. Biol. \& Med., 1943, 53, 30.

35. Beyer, K. H., Peters, L., Woodward, R., and Verwey, W. F., The enhancement of the physiological econ- omy of penicillin in dogs by the simultaneous administration of para-aminohippuric acid. J. Pharmacol. \& Exper. Therap., 1944, 82, 310.

36. Newman, E. V., Gilman, A., and Phillips, F. S., The renal clearance of thiosulfate in man. Bull. Johns Hopkins Hosp., 1946, 79, 229.

37. Goldring, W., and Chasis, H., Hypertension and Hypertensive disease. The Commonwealth Fund, New York, 1944.

38. Harrison, H. E., A modification of the diphenylamine method for determination of inulin. Proc. Soc. Exp. Biol. \& Med., 1942, 49, 111.

39. Smith, H. W., Lectures on the Kidney. (PorterWelch Lectures.) University Extension Division, University of Kansas, Lawrence, Kansas, 1943.

40. Chasis, H., Redish, J., Goldring, W., Ranges, H., and Smith, H. W., The use of sodium p-aminohippurate for the functional evaluation of the human kidney. J. Clin. Invest., 1945, 24, 583. 